\title{
Adaptive radiation at a low taxonomic level: divergence in buoyancy of the ecologically similar Antarctic fish Notothenia coriiceps and N. rossii
}

\author{
Joseph T. Eastman ${ }^{1, *}$, Esteban Barrera-Oro ${ }^{2,3}$, Eugenia Moreira ${ }^{2}$ \\ ${ }^{1}$ Department of Biomedical Sciences, Ohio University, Athens, Ohio 45701-2979, USA \\ ${ }^{2}$ Instituto Antártico Argentino and CONICET, Cerrito 1248, A1010AAZ Buenos Aires, Argentina \\ ${ }^{3}$ Museo Argentino de Ciencias Naturales 'Bernardino Rivadavia', A. Gallardo 470, CI405DJR, Buenos Aires, Argentina
}

\begin{abstract}
We studied the buoyancy of 263 specimens of the sympatric sister species Notothenia coriiceps and $N$. rossii captured at King George Island. In these species without a swim bladder, we expressed measurements of buoyancy as percentage buoyancy $(\% B=$ weight in water/weight in air $\times 100$ ), with smaller numbers reflecting more buoyant (i.e. less dense) species. Mean $\% B$ of $N$. coriiceps $(4.34 \%)$ was significantly greater than that of $N$. rossii $(3.82 \%)$, reflecting the lower density and more active swimming, migratory, and feeding behavior of $N$. rossii compared to $N$. coriiceps. Skeletal weight as a percentage of body weight was also significantly greater in N. coriiceps $(2.46 \%)$ than $N$. rossii $(1.65 \%)$. Paradoxically, the weight of the vertebral column as a percentage of skeletal weight was significantly greater in $N$. rossii $(28.01 \%)$ than in $N$. coriiceps $(24.29 \%)$; however, this is intelligible in light of the bone anatomy and histology. Our sample encompassed a wide size and age range, and trend lines for scatter plots of $\% B$ against standard length were curvilinear for both species, peaking at 140 to $160 \mathrm{~mm}$, a phenomenon not previously seen in studies of notothenioid buoyancy. We conclude that the ontogenetic increase in $\% B$ (reduced buoyancy) in fingerlings/young juveniles and the ontogenetic decrease in $\% B$ (increased buoyancy) in older juveniles/immature adults reflects disproportionate growth of skeletal and visceral tissues, respectively, and is not causally related to concurrent pelagic-demersal habitat shifts.
\end{abstract}

KEY WORDS: Notothenioid · Ontogenetic variation · Skeletal anatomy and histology • South Shetland Islands

\section{INTRODUCTION}

The isolated subzero waters of the Antarctic shelf are a fascinating but underappreciated evolutionary locale - a cold evolutionary hotspot (Eastman 2000, 2005). Here, radiations of vertebrates include 4 species of lobodontine seals (Deméré et al. 2003, Fyler et al. 2005) and 3 recently diverged species of killer whales, including a smaller form that inhabits dense pack ice and feeds on fish (LeDuc et al. 2008). Some lineages of invertebrates have also radiated, including bryozoans, pycnogonids, echinoderms, amphi. pods, and isopods (Brandt 1999, 2000, Brandt et al.
2007). The radiation of perciform notothenioid fish is especially noteworthy. With little competition from other fish groups, they have opportunistically expanded from a single benthic lineage into 5 families and 104 endemic Antarctic species, as well as into many different morphological and ecological types, including some that live in the water column in spite of the absence of a swim bladder. Differential use of benthic and water column habitats is the major ecological axis of the notothenioid adaptive radiation, and this is reflected in the divergent buoyancies of various species (Eastman \& DeVries 1982, Eastman 1993, Eastman \& Sidell 2002). Alterations in density 
and buoyancy are achieved through a combination of static mechanisms including reduced skeletal ossification, with persistent cartilage, and substantial accumulation of lipids within the white axial musculature or in subcutaneous tissue (DeVries \& Eastman 1978, Eastman \& DeVries 1981).

Although ecological selection is a major driver of speciation (Schluter 2000, 2009), the association between the divergent life histories of sister species of notothenioids and their differential buoyancies has received little attention. Notothenia coriiceps Richardson and N. rossii Richardson of the family Nototheniidae are a case in point. Both species have wide Antarctic distributions, particularly in shelf areas of the Scotia Arc (DeWitt et al. 1990). Their eggs, larvae, and early juvenile stages are pelagic, and presumably close to neutral buoyancy, but subsequently both species become demersal in coastal areas, inhabiting depths to $450 \mathrm{~m}$ (Tiedtke \& Kock 1989). At inshore sites in the South Shetland Islands, N. coriiceps is the dominant fish (Barrera-Oro 2002), whereas the population of $N$. rossii is still in the process of recovery after being a target of offshore commercial fishing in the late 1970s (Barrera-Oro \& Marschoff 2007). Studies at Potter Cove, on King George/25 de Mayo Island have shown that both species are generalist feeders that have similar ecology in the fjords, living predominantly at 5 to $50 \mathrm{~m}$ depths on rocky bottoms with beds of macroalgae (DeWitt et al. 1990, Barrera-Oro 2002).

Data on age, gonadal stages, and depth distribution of Notothenia coriiceps at Potter Cove suggest that sexual maturity is first reached at about $6 \mathrm{yr}$ and that some component of the population spends its entire life inshore (Casaux et al. 1990). Although inshore spawning was also documented for the population of N. coriiceps at South Georgia (Burchett et al. 1983), pre-spawning aggregations found off Elephant Island and north of King George/25 de Mayo Island indicate that this species also migrates to deeper coastal waters to spawn (Balguerías 1989, Kock 1989, Jones et al. 2003). N. rossii occurs in Potter Cove at ages 0 to $6-7 \mathrm{yr}$, an exclusively juvenile stage in their life (Barrera-Oro \& Casaux 1992, Barrera-Oro et al. 2010), after which they migrate offshore to join and spawn with the adult population (Burchett 1982).

Are there differences in the buoyancies of closely related, ecologically similar species of notothenioids? Here we focus on sympatric sister species that form a crown clade in the notothenioid radiation. Because they share a common ancestry (Near et al. 2004, Sanchez et al. 2007, Near \& Cheng 2008), Notothenia coriiceps and N. rossii are ideal for examining the as- sociation between buoyancy and ecological diversification within the spectrum of benthic life styles. Despite the ecological resemblances, $N$. coriiceps is more demersal and sedentary (North 1996), and feeds on a wider range of benthic organisms, whereas $N$. rossii is semipelagic and migratory, feeding regularly on water column prey, when available, during the summer months (Barrera-Oro \& Casaux 1990, Casaux et al. 1990). These differences in their utilization of the water column are more pronounced in deeper offshore waters (Barrera-Oro 2002). A previous study using a few relatively small specimens noted that differences in body shape and time spent in the water column were consistent with measured buoyancies for $N$. coriiceps and $N$. rossii (Eastman \& Sidell 2002). However, studies of buoyancy to date have involved small sample sizes, usually fewer than 30 individuals. Furthermore, consideration of ontogenetic variation in buoyancy has been ignored or confined to the subadult-adult size range in a few species, excluding $N$. coriiceps and N. rossii, with results showing an increase in buoyancy with increasing body length and weight (Eastman \& Sidell 2002, Near et al. 2003). Nothing is known about the buoyancies of larvae or newly settled juveniles in any notothenioid species, although a loss of buoyancy would be expected as they transition from pelagic larvae to benthic juveniles.

In summer, the waters of Potter Cove are usually calm and ice-free, and an extended period of fieldwork permitted us to collect and to perform measurements of buoyancy on a large sample, with wide size and age ranges, of Notothenia coriiceps and N. rossii. The sample included all life history stages available inshore, from early juveniles of both species to large adults of $N$. coriiceps and large juveniles and subadults of $N$. rossii. Analysis of this material allowed us to compare $N$. coriiceps and $N$. rossii with respect to (1) values for percentage buoyancy and ontogenetic trends in buoyancy, including data for the smallest juvenile specimens of any notothenioid; (2) skeletal weights and vertebral anatomy and histology; and (3) ecology as related to buoyancy and ontogenetic changes in buoyancy.

\section{MATERIALS AND METHODS}

\section{Collection of specimens}

We collected 103 specimens of Notothenia coriiceps and 167 of N. rossii at Potter Cove, King George/25 de Mayo Island, South Shetland Islands, close to the scientific station Jubany $\left(62^{\circ} 14^{\prime} \mathrm{S}, 58^{\circ} 40^{\prime} \mathrm{W}\right)$, from 
7 December 2009 to 22 February 2010 and from 14 September to 5 November 2010. The biotic components and abiotic features of this area are described in Casaux et al. (1990). The fish were caught at depths of 6 to $40 \mathrm{~m}$ by means of a bottom trawl (mesh $4 \mathrm{~mm}$ ) and trammel nets (inner mesh $25 \mathrm{~mm}$ ) deployed from rubber boats. Eastman \& Barrera-Oro (2010) provide a more detailed description of gear, sampling procedure, and maintenance of fish in aquaria prior to measurements of buoyancy. Our preliminary statistical analysis identified 5 specimens (4 $N$. coriiceps and $1 N$. rossii) as having outlying values for relative buoyancy in box plots and 2 ( $N$. rossii) as having erroneous weights in air. Thus, only 263 of the 270 fish caught were used in the analysis of buoyancy.

\section{Laboratory procedures and measurements}

In the laboratory at Jubany, we obtained total length $(\mathrm{TL}, \mathrm{mm})$ and standard length $(\mathrm{SL}, \mathrm{mm})$ of the fish and determined their buoyancy. This involved weighing the fish in water of a temperature similar to that of the habitat and then in air. We expressed our measurements of buoyancy as percentage (or relative) buoyancy $(\% B)$, i.e. the percentage of the body weight $(W)$ in air supported when in the water:

$$
\% B=W_{\text {water }} / W_{\text {air }} \times 100
$$

We followed the protocol for the procedure and apparatus used in making buoyancy measurements summarized by Near et al. (2009). Specimens of medium to large size were anesthetized before weighing. We used electronic balances with accuracies of $0.01 \mathrm{~g}$ and $0.001 \mathrm{~g}$ for smaller and larger ( $>220 \mathrm{~mm}$ SL) specimens, respectively. Water temperature in the container used for measurements was 1 to $2^{\circ} \mathrm{C}$. Errors in measurements of buoyancy attributable to changes in temperature, salinity, and pressure (water depth) are small, totaling only about $+0.15 \%$ of the weight of the fish in air (Corner et al. 1969) and are usually disregarded (Denton \& Marshall 1958).

We determined sex and maturity stages of some specimens on the basis of a 5-point scale used for notothenioids (Kock \& Kellermann 1991). For both species, we estimated the age range by reading scales from a limited number of the smaller (Notothenia coriiceps $\leq 59 \mathrm{~mm} \mathrm{SL}$; $N$. rossii $\leq 72 \mathrm{~mm} \mathrm{SL}$ ) and larger ( $N$. coriiceps $\geq 390 \mathrm{~mm} \mathrm{SL} ; N$. rossii $\geq 363 \mathrm{~mm}$ SL) specimens. We followed a method of counting annuli similar to that described by Barrera-Oro \& Casaux (1996) for N. coriiceps and by Barrera-Oro \&
Casaux (1992) and Barrera-Oro et al. (2010) for $N$. rossii.

Soon after obtaining buoyancy measurements, most of the fish were released alive at the sampling site. Given that variables such as gut contents, normal variation in nutritional condition, sex, and reproductive state are inherent components of $\% B$ measurements (Near et al. 2009), we preferred not to sacrifice a large number of fish unnecessarily. It has been demonstrated that intensive sampling of fish at Potter Cove, even for scientific purposes, disrupts the normal structure of the populations (Casaux \& Barrera-Oro 2002). Therefore, we cannot provide a sex ratio for the sample.

We also calculated a Fulton-type condition factor (Anderson \& Gutreuter 1983), K, scaled to center around 1.0, as an index of weight per unit length and as an indirect estimate of fish girth (Davidson \& Marshall 2010) and thus a proxy for body shape:

$$
K=\left(W / \mathrm{TL}^{3}\right) \times 10^{5}
$$

where $W$ is measured in $g$. Larger values for $K$ indicate greater weight per unit length associated with a thicker body. We are not employing $K$ as an indicator of body fat content.

As another gauge of body shape and weight (and presumably also volume) as a function of length, we used these same variables to compute a lengthweight relationship for each species:

$$
W=a \mathrm{TL}^{b}
$$

We obtained the values for the power function by linear regressions of ln-transformed data where $a$ is a constant and $b$ is an exponent. Values of $b>3$ indicate positive allometry, and higher values also suggest a more rotund body shape, viz. greater weight per unit length (Jobling 2002).

\section{Anatomical and histological techniques}

We prepared dry skeletons from frozen specimens of each of 3 relatively large Notothenia coriiceps (220-372 mm SL) and N. rossii (219-363 mm SL). This involved macerating the fish in soapy water for 2 to $3 \mathrm{~d}$ at room temperature $\left(23^{\circ} \mathrm{C}\right)$, cleaning the bones with running water and compressed air, and drying at room temperature to a constant weight (4 wk).

We used 1 formalin-preserved specimen (265$280 \mathrm{~mm} \mathrm{SL}$ ) of each species to examine bone histology of vertebral centra in an area of the column centered on the first caudal vertebra. We removed 4 to 7 longitudinal and transverse pieces of the column in 
this region, decalcified them for 19 to $48 \mathrm{~h}$ in a commercial solution containing EDTA in dilute $\mathrm{HCl}$, and post-fixed them in Bouin's solution. We then embedded samples in paraffin according to standard procedures. We cut $7 \mu \mathrm{m}$ thick sections on a rotary microtome, mounted sections on slides, and deparaffinized and then stained them with Gomori's 1-step trichrome or with Bodian's Protargol for $24 \mathrm{~h}$ at $50^{\circ} \mathrm{C}$.

\section{Statistical analysis}

We used the programs Excel and SPSS 16.0 for statistical analysis. Kolmogorov-Smirnov and ShapiroWilk tests indicated that $\% B$ values were normally distributed. Because $\% B$ is a ratio, we performed an arcsine transformation to ensure that the variance was independent of the mean (Sokal \& Rohlf 1981). We used independent $t$-tests to compare equality of means between the 2 species. Data values in the text are untransformed but reported levels of significance are for arcsine-transformed data. Our null hypotheses were that there were no differences between the 2 species in means for $\% B$, percentage skeletal weight, percentage vertebral column weight, and $K$. To examine ontogenetic trends in $\% B$, we graphed untransformed data in scatter plots and fitted trend lines using the curve-fitting procedure that provided the highest values for $r^{2}$ (provided the lines were supported by the distribution of data points) and the most significant values for $\mathrm{p}$ in ANOVA.

\section{RESULTS}

\section{Size, length-weight relationship, age, and gonadal stages}

Fig. 1 shows the length-frequency distribution of Notothenia coriiceps and $N$. rossii. Additional size and life history information is provided in Table 1. The sample included a similarly wide range of sizes
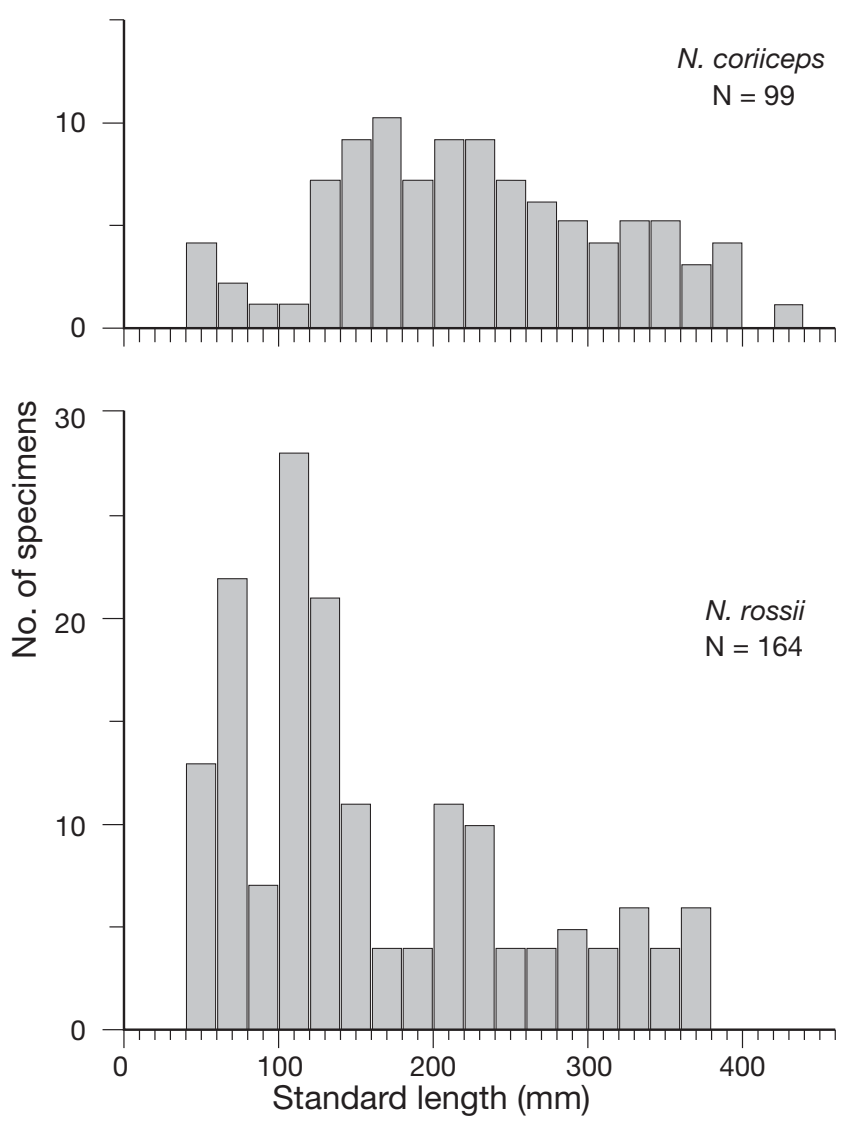

Fig. 1. Notothenia coriiceps and N. rossii. Length-frequency distribution for 263 specimens sampled at Potter Cove for measurements of buoyancy

for both species, from small juveniles of $N$. coriiceps (64 mm TL, $55 \mathrm{~mm} \mathrm{SL}, 2.66 \mathrm{~g}$ ) and $N$. rossii $(63 \mathrm{~mm}$ $\mathrm{TL}, 54 \mathrm{~mm} \mathrm{SL}, 2.77 \mathrm{~g}$ ) to large adults of $N$. coriiceps (475 mm TL, $420 \mathrm{~mm} \mathrm{SL}, 1571 \mathrm{~g}$ ) and large juveniles of $N$. rossii (436 mm TL, $378 \mathrm{~mm} \mathrm{SL}, 1170 \mathrm{~g}$ ). The youngest and oldest $N$. coriiceps belonged to age groups 1 and $14 \mathrm{yr}$, which is in agreement with the age information reported by Kellermann (1991) for pelagic juveniles of 55 to $60 \mathrm{~mm}$ SL and by Casaux et al. (1990) for adults larger than about $420 \mathrm{~mm}$ SL. Likewise, $N$. rossii of age groups 1 to $7 \mathrm{yr}$ were repre-

Table 1. Notothenia coriiceps and N. rossii. Size and life history information for 263 specimens sampled from Potter Cove, King George/25 de Mayo Island, South Shetland Islands. TL: total length; SL: standard length; $W$ : body weight; $K$ : Fulton-type condition factor. TL, SL, $W$, and $K$ are mean values with ranges in parentheses. \% of maximum reported TL is based on $620 \mathrm{~mm}$ for $N$. coriiceps and $920 \mathrm{~mm}$ for N. rossii (DeWitt et al. 1990). Gonadal stage is based on maturity scale of Kock \& Kellermann (1991)

\begin{tabular}{|lccccccccc|}
\hline Species & N & TL & SL & $W$ & $\begin{array}{c}\text { \% of max. } \\
\text { reported TL }\end{array}$ & $K$ & $\begin{array}{c}\text { Length-weight } \\
\text { relationship }\end{array}$ & $\begin{array}{c}\text { Age } \\
\text { group }\end{array}$ & $\begin{array}{c}\text { Gonadal } \\
\text { stage }\end{array}$ \\
\hline N. coriiceps99 & $265(64-475)$ & $226(55-420)$ & $410(3-1571)$ & $10-77$ & $1.44(0.85-1.81)$ & $4.48 \times 10^{-6}(\mathrm{TL})^{3.21}$ & $1-14$ \\
N. rossii 164 & $189(63-436)$ & $162(54-378)$ & $184(3-1170)$ & $7-47$ & $1.23(0.89-1.60)$ & $6.64 \times 10^{-6}(\mathrm{TL})^{3.12}$ & $1-7$ & $1-2$ \\
\hline
\end{tabular}


sented in our sample, consistent with data previously obtained at the same site (Barrera-Oro \& Casaux 1992, Barrera-Oro et al. 2010). Stages of gonadal development were 1 (immature) to 3 (developing) in $N$. coriiceps and 1 to 2 (maturing virgin) in N. rossii.

\section{Buoyancy values and ontogenetic changes in buoyancy}

Fig. 2 displays the results of our measurements of buoyancy and descriptive statistics for Notothenia coriiceps and $N$. rossii. As indicated by Kolmogorov-Smirnov ( $\mathrm{p}=0.200)$ and Shapiro-Wilk ( $\mathrm{p}=0.308$ to 0.974 ) tests, values for $\% B$ were normally distributed in both species. Values encompassed a range of $1.3 \% B$ units for $N$. coriiceps and $2.0 \% B$ units for $N$. rossii, the former typical of intraspecific variation in this measurement for notothenioids (Eastman \& Sidell 2002, Near et al. 2009) and the latter somewhat larger because of the larger number of smaller SL specimens involved. There was also a routine amount of dispersion (SD) around the mean -0.26 to $0.42 \% B$ units. An independent sample t-test assuming unequal variances indicated that the mean $\% B$ of $N$. coriiceps $(4.34 \%)$ was significantly larger $(t=$ $12.242, \mathrm{p}<0.0001)$ than that of $N$. rossii $(3.82 \%)$.
The non-overlapping $95 \%$ confidence levels in Fig. 2 also reflect statistical significance.

When we examined scatter plots of the data points for $\% B$ versus SL, the variables were not linearly related, and linear regression yielded values for $\mathrm{r}^{2}$ of 0.135 for Notothenia coriiceps and 0.0003 for $N$. rossii. Therefore, we fitted trend lines with locally weighted regression scatterplot smoothing (LOWESS), a method designed to reveal the dependence of $y$ on $x$ when the signal is embedded in a diffuse scatter plot. The resulting lines were curvilinear and similar for both $N$. coriiceps and $N$. rossii (Fig. 3a). Because the LOWESS method does not provide an $\mathrm{r}^{2}$ value, we employed other curve estimation regression models. A quadratic model provided the best fit with values for $\mathrm{r}^{2}=0.441-0.522$ (Fig. 3b) and ANOVAs with values of $p<0.0001$. Equations for the quadratic model in Fig. 3b are:

$$
\text { for } N \text {. coriiceps: } \begin{aligned}
y & =3.958+0.005 x-0.00001314 x^{2} \\
t & =27.116, p<0.0001
\end{aligned}
$$

and for N. rossii: $y=2.887+0.013 x-0.00003168 x^{2}$;

$$
t=23.326, \mathrm{p}<0.0001
$$

The trend lines in Fig. 3a,b show ontogenetic change in $\% B$ with increasing length. Our sample had relatively few small specimens of $N$. coriiceps,

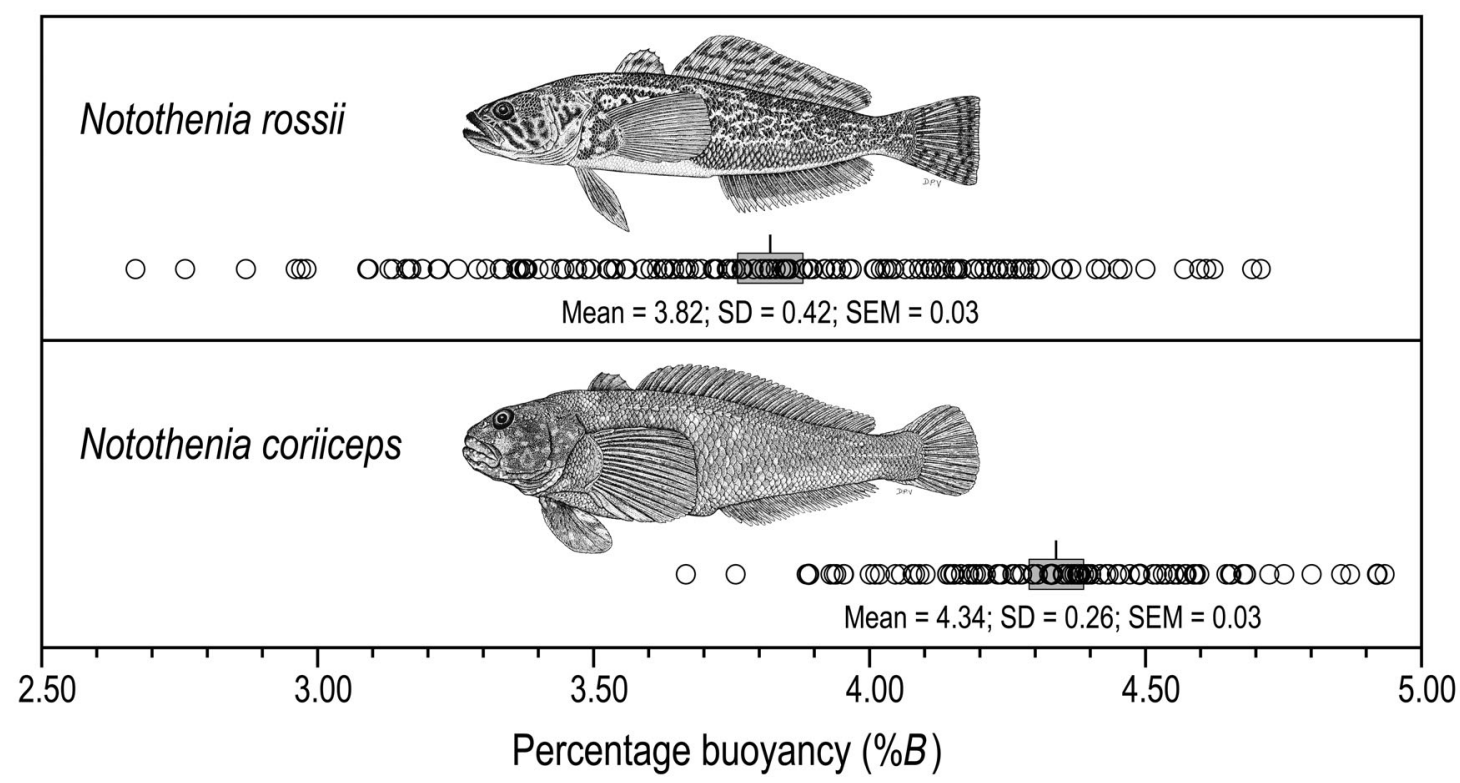

Fig. 2. Notothenia coriiceps and N. rossii. Measurements of percentage buoyancy and descriptive statistics for 99 specimens of $N$. coriiceps and 164 specimens of N. rossii from Potter Cove. Circles are individual measurements, vertical lines are means, and shaded rectangles are $95 \%$ confidence intervals for the mean. Illustrations of the 2 species show body shape and general morphology and are the work of D. P. Voorvelt in DeWitt et al. (1990). Reproduced from Gon \& Heemstra (1990) with permission; copyright by the J.L.B. Smith Institute of Ichthyology (now the South African Institute for Aquatic Biodiversity) 

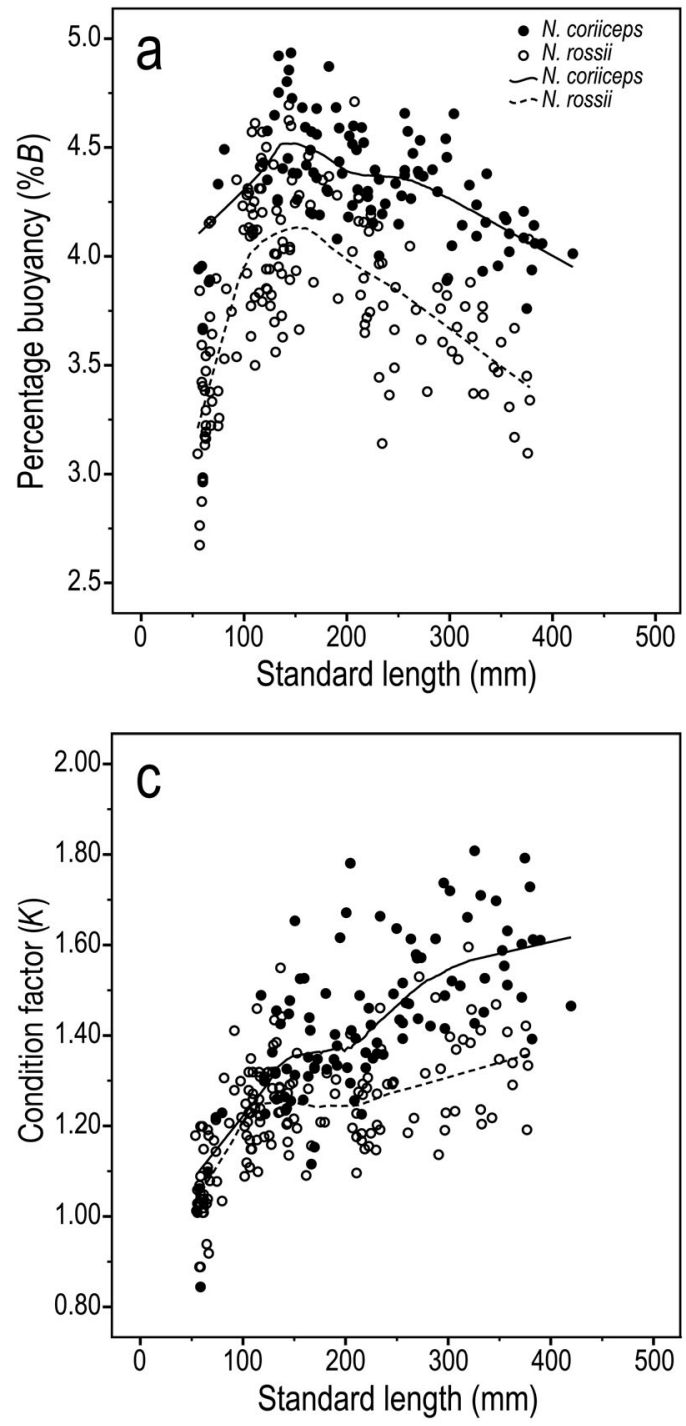

although we had a large sample of 75 smaller specimens (54 to $125 \mathrm{~mm} \mathrm{SL}$ ) of $N$. rossii. Nevertheless, similar trend lines for both species indicate that in this phase of late larval/early juvenile life the $\% B$ increases (meaning decreased buoyancy and increased density). This relationship has not been reported previously, but we have measured a sufficiently large number of small specimens, especially for $N$. rossii, that we are convinced of the validity of this finding. The trend lines for $\% B$ reach inflection points at about $140 \mathrm{~mm}$ SL in $N$. coriiceps and $160 \mathrm{~mm}$ SL in $N$. rossii and then decrease to a level about $0.5 \% B$ units lower in the largest specimens of $N$. coriiceps $(\sim 400 \mathrm{~mm} \mathrm{SL})$. The ontogenetic decline in $\% B$ (increased buoyancy/decreased density) was more pronounced in $N$. coriiceps and amounted to about $0.75 \% B$ units for the large specimens of 350 to $400 \mathrm{~mm}$ SL.

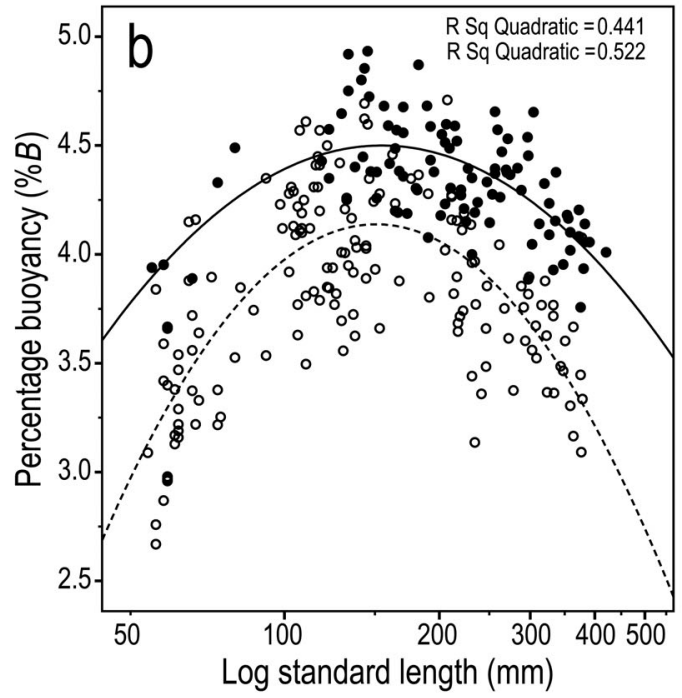

Fig. 3. Notothenia coriiceps and N. rossii. Bivariate scatter plots of $(a, b)$ percentage buoyancy versus standard length and (c) condition factor versus standard length. Trend lines in (a) and (c) fitted by the LOWESS method (see 'Results' for details) and in (b) by a quadratic model

\section{Body shape and ontogenetic changes in condition factor}

The illustrations in Fig. 2 show the external morphology of the 2 species. Notothenia coriiceps is a heavy rugged fish with a large, wide depressed head. $N$. rossii, on the other hand, is more gracile, with a laterally compressed and streamlined body. The more rotund body of $N$. coriiceps is also reflected in the significantly larger mean $K$ of 1.44 versus 1.23 in $N$. rossii $(t=10.592, \mathrm{p}<0.0001)$ and in the greater exponent of the length-weight relationship (Table 1). Both imply that, relative to $N$. rossii, $N$. coriiceps has a greater weight per unit length that is associated with a thicker body.

The trend lines for $K$ versus length (Fig. 3c) are similar for Notothenia coriiceps and N. rossii, with positive slopes, although the slope is greater in N. coriiceps. Given that the $\mathrm{r}^{2}$ values of linear trend lines were relatively low, we fitted lines using LOWESS. The lines temporarily plateaued at $150 \mathrm{~mm}$ SL ( $N$. coriiceps) or plateaued and decreased slightly at $120 \mathrm{~mm}$ SL (N. rossii) and then began to increase again at $200 \mathrm{~mm}$ SL in both species. We interpret this upturn at $200 \mathrm{~mm}$ SL as indicating the size at which growth of soft tissues (muscle, viscera, adipose) begins to outpace growth of skeletal tissues, thus decreasing the density and increasing the buoyancy of the body. In Fig. 3a,b, this corresponds to inflection 
points and negative slopes of the trend lines where $\% B$ begin to decrease. Finally, when the lengthweight relationship in Table 1 is graphed (not shown), the slope also begins to ascend steeply at about $200 \mathrm{~mm}$ SL in both species.

\section{Skeletal weights and vertebral anatomy and histology}

In accordance with our measurements of buoyancy, a proxy for density, we found that mean dry skeletal weight as a percentage of body weight was significantly greater in 3 specimens of Notothenia coriiceps $(2.46 \%)$ compared to 3 specimens of comparable size in $N$. rossii $(1.65 \% ; t=5.611, \mathrm{p}<0.03)$. Paradoxically, the weight of the vertebral column as a percentage of skeletal weight was significantly greater in $N$. rossii $(28.01 \%)$ than in $N$. coriiceps $(24.29 \% ; t=-3.766, \mathrm{p}<$ $0.02)$; however, this is intelligible in light of the bone morphology.

Fig. 4 shows the anatomy (Fig. 4a,b,e) and histology (Fig. 4c,d,f) of vertebrae from identical locations in specimens of Notothenia coriiceps and N. rossii of similar length. The nature of bone, whether spongy (light and porous) or compact (heavy), can increase its density by 4 -fold (Wainwright et al. 1976). Cavities in spongy bone decrease the bone mass and decrease overall body density by also providing space for low-density lipid (Pelster 1998). In both $N$. coriiceps and $N$. rossii, the only compact bone in the vertebrae is confined to a small area of the centrum bordering the intervertebral area (Fig. 4e). The majority of the centrum is composed of spongy bone with lipid-filled cavities of various sizes. The lipid is contained in typical adipocytes (Fig. 4f). There are, however, differences between the 2 species. In the centra of $N$. coriiceps (Fig. $4 \mathrm{a}, \mathrm{c}$ ) the volume of the bone space is less and that of cavity space is more than in N. rossii (Fig. 4b,d). Surface area measurements (\%) of the spongy bone in Fig. 4c,d give a bone:cavity ratio of 44:56 for $N$. coriiceps and 63:37 in $N$. rossii. Thus, N. rossii has more bone and less lipid-containing cavity space, and this accounts for the significantly greater relative weight of the vertebral column in this species. Cavities are formed during development when space filled with loose connective tissue becomes incorporated into periosteal bone (de Ricqles et al. 1991). These cavities are therefore normal morphology for spongy bone in these species and, as evidenced by their smooth walls (Fig. 4f), are not the results of bone remodeling by osteoclastic activity.

\section{DISCUSSION}

With a sample size consisting of 99 specimens of Notothenia coriiceps and 164 of $N$. rossii, we have made the largest number of measurements of buoyancy performed on any notothenioid to date. In addition, our sample encompasses a considerable size and age range, including, for the first time, very small specimens (54-55 $\mathrm{mm}$ SL and $\sim 3 \mathrm{~g}$ ). The mean $\% B$ values for the 2 species were significantly different, as was the case with those obtained for the same species sampled $2^{\circ}$ of latitude farther south at Brabant Island, Palmer Archipelago (Eastman \& Sidell 2002). Mean values for our specimens from Potter Cove were 0.2 to $0.3 \% B$ units higher, but this is within the bounds of $N$. rossii normal intraspecific variation (usually ca. $0.2-0.5 \% B$ units) for this measurement in populations from different localities (Near et al. 2009).

\section{Ontogenetic changes in buoyancy}

Ontogenetic changes in $\% B$ in both species showed a curvilinear relationship with body length. Using Notothenia rossii as an example because we had a larger number of smaller specimens for this species, \% $B$ values for fingerlings/small juveniles (ca. 50-60 mm SL) were 2.7 to 3.0 , and values increased precipitously to peak at about 4 and then decreased to $3.25-3.50$ in large juveniles (350-375 $\mathrm{mm}$ SL) that are $<50 \%$ of maximum TL (Table 1). The metamorphosis from pelagic to demersal life takes place early in the ascent phase of the curve, and this period of decreasing buoyancy/increasing density is coincident with the settling of small juveniles of these and other nototheniid species to the bottom among the macroalgae of Potter Cove (Barrera-Oro \& Piacentino 2007, Barrera-Oro \& Winter 2008). In N. coriiceps, this is also when subcutaneous lipid sacs disappear as muscle fiber types become redistributed (Johnston \& Camm 1987), also possibly contributing to an increase in density. As to the decrease in $\% B$ in the descent phase of the curve (Fig. 3a,b), we can confidently say that in the case of $N$. rossii, this is unrelated to gonadal maturity because all specimens had immature stage 1 to 2 gonads, similar to (with minor exceptions) the results of a previous study also carried out in Potter Cove (Casaux et al. 1990). A curvilinear buoyancy relationship has not been previously reported for any notothenioid. The only prior studies of ontogenetic change in buoyancy involving 2 channichthyids and 3 nototheniids showed a linear 


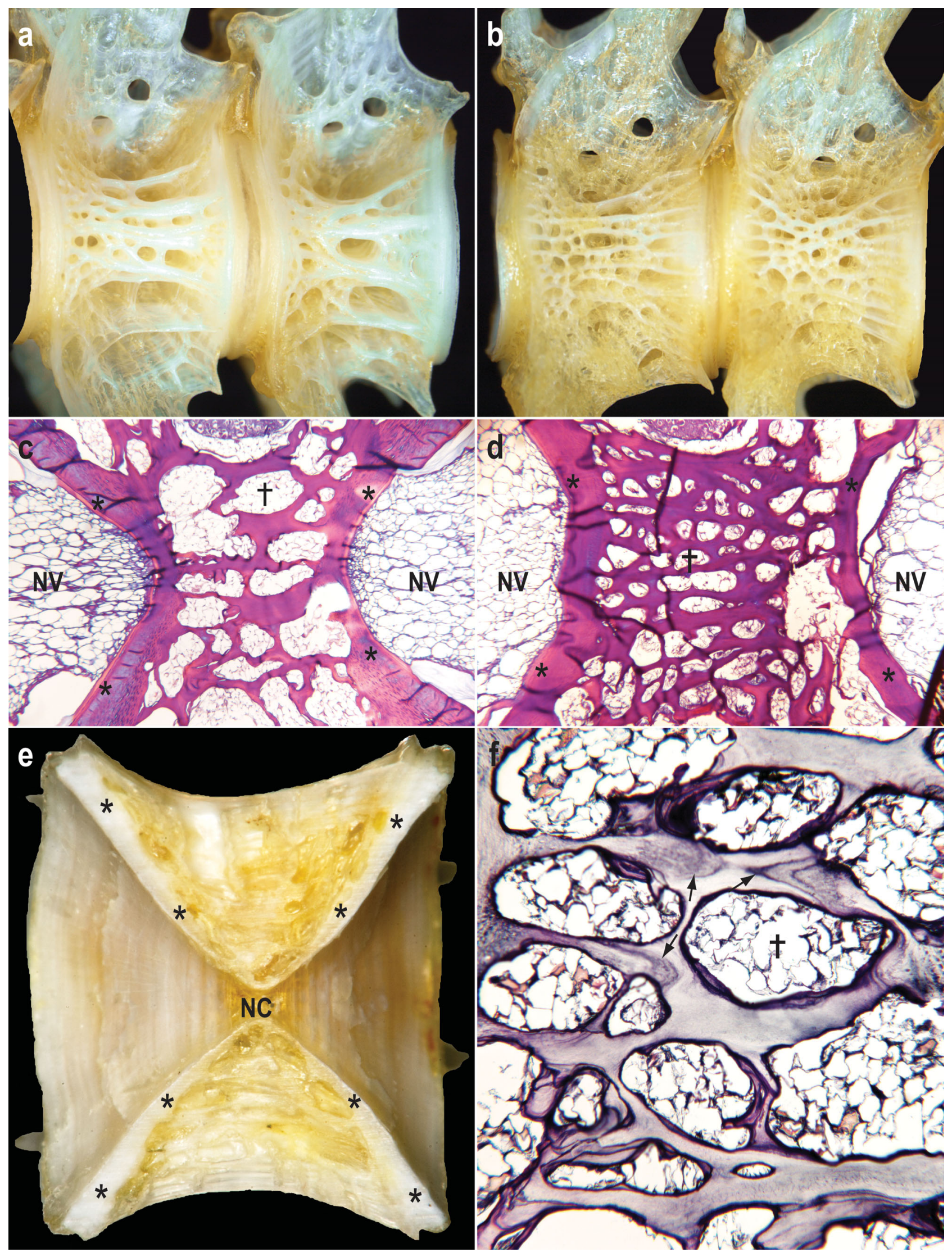


relationship versus SL with a negative slope (Eastman \& Sidell 2002, Near et al. 2003). We must note, however, that small juveniles were not included in these previous studies and thus we cannot address the universality of the curvilinear relationship we found in our sample. However, it is evident that increasing buoyancy/decreasing density is a general phenomenon in the late juvenile and adult stages of life for the 7 notothenioid species studied to date, with the likely exception of the post-spawning and starving 'axe handle' specimens of Dissostichus mawsoni (Fenaughty et al. 2008). We are thus attributing the curvilinear relationship of the $\% B$ curve to the nature of growth in $N$. coriiceps and $N$. rossii (see below) rather than to a specific pelagic-demersal habitat shift or to a migratory phase in their life history.

\section{Buoyancy: morphological and ecological perspectives}

As mentioned previously, $\% B$ values are a proxy for body density which depends on the proportions and densities for the various tissues of the body (Alexander 1968). The curvilinear relationship in $\% B$ values is consistent with what is known about both growth in general and relative growth rate in individual tissues. Although fish grow throughout life (Weatherley 1972), various tissues exhibit different rates of growth (Mommsen 1998). As larvae grow and the skeleton ossifies, they become heavier and buoyancy decreases (Blaxter 1988). The ascent phase of our \%B curve (Fig. 3a,b) reflects this decrease in buoyancy during late larval and early juvenile life. The descent phase of the curve, indicating an increase in buoyancy, is associated with continuing growth but in a different way. Changes in weight during growth are relatively greater than changes in length given that the expo- nent is $\sim 3$ (Table 1) in the length-weight relationship (Busacker et al. 1990). Whereas increase in length represents growth of high-density skeletal tissues, increase in weight reflects growth of relatively lowdensity muscle and viscera with its associated lipid (Donaldson et al. 1979, Mommsen 1998). This is also evidenced by the rise in $K$ at about $200 \mathrm{~mm}$ SL in both Notothenia coriiceps and N. rossii (Fig. 3c).

The significantly different mean $\% B$ values for the sister species Notothenia coriiceps and N. rossii are consistent with inferences from body morphology with the divergence in adult ecology. Although both $N$. coriiceps and N. rossii possess similar blue-silverphase pelagic fingerling stages, they subsequently diverge in the degree of 'benthicity.' With a wide head and heavy rotund body, large juvenile and adult $N$. coriiceps epitomize a sedentary benthic notothenioid. For example, a $330 \mathrm{~mm}$ TL specimen monitored with an underwater video camera at Signy Island, South Orkney Islands, remained within $3 \mathrm{~m}$ of a small cave $>98 \%$ of the during a $24 \mathrm{~h}$ period and swam only $1.7 \%$ of each day, usually for $<30 \mathrm{~s}$ (North 1996). The body morphology of $N$. coriiceps is also suitable for habitation of the tidal surge zone where they lurk and feed between rocks in extremely shallow water. Adults rely predominantly on labriform locomotion at low speeds, with occasional bursts of subcarangiform swimming (Archer \& Johnston 1989). Activity and feeding comprised only $5.7 \%$ of the total metabolic rate in $N$. coriiceps from Adelaide Island, SW Antarctic Peninsula (Campbell et al. 2007), where they also enter into an inactive dormant state in the winter (Campbell et al. 2008). The population of $N$. coriiceps in Potter Cove may spend its entire life cycle in that location without migrating offshore to feed or breed (Casaux et al. 1990). Moreover, the strong site fidelity of $N$. coriiceps has been demonstrated in a tag-recapture experiment at Potter Cove,

Fig. 4. Notothenia coriiceps and N. rossii. Anatomy and histology of bone in vertebral centra of (a,c,e,f) N. coriiceps and (b,d) N. rossii. $(\mathrm{a}, \mathrm{b})$ Left lateral views of the centra of the last abdominal and first caudal vertebrae (standard length and weight: $N$. coriiceps $=372 \mathrm{~mm}, 1239.4 \mathrm{~g}$; N. rossii $=363 \mathrm{~mm}, 978.9 \mathrm{~g}$ ). Both specimens have 53 total vertebrae. Both species have predominantly spongy bone, but the mesh is finer (smaller cavities, larger bony trabeculae) in N. rossii. Magnifications, $\times 6.6$ and $\times 7.1$. $(\mathrm{c}, \mathrm{d})$ Parasagittal histological sections of bone in centra of anterior caudal vertebrae, showing distribution of red-staining bony trabeculae and lipid-filled spaces in the centrally located spongy bone. Compact bone (asterisks) of the amphicelous centra is located at the periphery adjacent to notochordal cavities filled with notochordal vacuoles (NV). Long axes of spaces marked by crosses are $420 \mu \mathrm{m}$ and $225 \mu \mathrm{m}$, respectively. Stain: Gomori's trichrome. $\times 25$ and $\times 25$. (e) Midsagittal section of anterior caudal vertebra of $N$. coriiceps, sanded to show the limited extent of compact bone (asterisks) and its location around the notochordal cavities with remainder of centrum consisting of spongy bone. This species has a small notochordal canal (NC) in the middle of each centrum. $\times 11$. (f) Parasagittal histological section of anterior caudal vertebra of $N$. coriiceps showing acellular nature of spongy bone and smooth-walled, lipid-filled cavities that are a normal feature, not attributable to recent erosion by osteoblasts. The lipid in these cavities is contained in adipocytes. Stain: Bodian's protargol. Arrows indicate accumulation of silver stain at growth checks in bone; these are not osteocytes. Long axis of space marked by cross is $420 \mu \mathrm{m} . \times 78$ 
where specimens were recovered at the same specific sampling sites after periods of 11 to 21 mo (Barrera-Oro \& Casaux 1996). In general, $N$. coriiceps is 'primarily a benthic predator' on amphipods, isopods, mollusks, and macroalgae (DeWitt et al. 1990).

Notothenia rossii is semipelagic or benthopelagic rather than strictly benthic, with a migratory period during its life cycle (DeWitt et al. 1990). Compared to $N$. coriiceps, $N$. rossii possesses a narrower head and more streamlined trunk, exhibits less modification of the pelvic fins for substrate contact, shows more spontaneous activity in captivity, and frequently employs subcarangiform locomotion (J. T. Eastman \& E. Barrera-Oro pers. obs.). The less rotund body of $N$. rossii is also reflected in the lower $K$ and the smaller exponent in the length-weight relationship (Table 1). The skeletal weight as a percentage of body weight is significantly less in $N$. rossii than in $N$. coriiceps, as would be expected in a less dense, more buoyant species. However, the percentage of vertebral column weight to total skeletal weight is significantly greater in $N$. rossii than in N. coriiceps. This is substantiated by the greater surface area (as a proxy for mass) of spongy bone seen in histological sections of vertebral centra. Our hypothesis for this seemingly contradictory finding is that it reflects the greater amount of time that $N$. rossii spends engaged in subcarangiform locomotion. This mode of locomotion involves lateral undulation of the posterior one-third to one-half of the trunk (Lindsey 1978), and the resultant compression and tension forces are applied to the vertebral column (Wainwright 1983). Because the vertebral column of $N$. rossii is subject to greater mechanical stresses than that of $N$. coriiceps, it is stiffer with more bone mass (Wainwright et al. 1976).

Although relatively large, the Notothenia rossii in Potter Cove are exclusively juveniles and will migrate offshore to feed and reproduce. This species feeds more frequently than $N$. coriiceps on water column prey (e.g. krill, hyperiid amphipods) when available during the summer months at Potter Cove (Casaux et al. 1990, Barrera-Oro \& Casaux 2008). As adults, N. rossii also feed heavily on krill (Burchett 1983, Kock 1985) throughout the water column. Krill are available all year in the lower Scotia Arc around the South Orkney Islands, South Shetland Islands, and western Antarctic Peninsula, where N. rossii is considered primarily a pelagic feeder with krill making up 90 to $100 \%$ of the diet by occurrence (Kock 1985). At South Georgia, the offshore population consumes krill almost exclusively, and in the summer, schools of $N$. rossii feed on krill at the surface (Olsen 1954).

\section{CONCLUSIONS}

Notothenioid fish have radiated on the Antarctic shelf and dominate taxonomic and functional biodiversity as well as abundance and biomass. It is the only known large marine ecosystem that is so overwhelmingly dominated by a single lineage of closely related teleost species (Eastman 2005). Notothenioids are among the numerous examples of the convergent loss of the swim bladder among teleost fishes - an event that has occurred independently at least 30 to 32 times (McCune \& Carlson 2004). However, the $100+$ species of notothenioids are unique in filling most water column and benthic niches on the High Antarctic shelf and slope, a contingency facilitated by the eradication of previous faunas by tectonic, oceanographic, and climatic changes over the last 25 million years. The only similar radiation in buoyancy and ecology in a group without a swim bladder is that of the approximately 30 species of cottoid sculpins from Lake Baikal in Siberia (Sideleva 1996, Kontula et al. 2003).

We have presented an example of adaptive radiation at a low taxonomic level that is associated with morphological and ecological divergence along the axis of buoyancy and habitat use, and is thus consistent with the dominant theoretical model of adaptive radiation (Schluter 2000, 2009). We found that the buoyancies of 2 sympatric sister species of Notothenia are significantly different by about $0.5 \% B$ units. Although both are relatively heavy and fall within a broad benthic/demersal category, their divergent buoyancies do reflect morphological and ecological separation associated with differences in body shape, skeletal weight, activity patterns, mode of swimming, and diet. These and other published data collectively indicate that Notothenia rossii is more semipelagic or benthopelagic than $N$. coriiceps. Our large sample encompassed a wide range of sizes and ages and is the first to reveal a curvilinear relationship between $\% B$ and length in notothenioids. There is an ontogenetic decrease in buoyancy that is concurrent with the transition from pelagic larval life to the benthic habitat of early juveniles. When juveniles reach 140 to $160 \mathrm{~mm} \mathrm{SL}$, buoyancy begins to increase. We do not attribute these changes in buoyancy directly to shifts in habitat but rather to consequences of the typical pattern of fish growth characterized by enhanced growth in low-density soft tissues with increasing size. In the case of $N$. rossii, the increase in buoyancy in late juvenile life precedes the offshore migratory, reproductive, and pelagic krill-feeding stages of adult life. Although not represented in our sample, it 
is possible that buoyancy continues to increase in large adult $N$. rossii as they feed on lipid-rich krill.

Acknowledgements. We thank C. Bellisio, L. Vila, and O. González for their help in field activities and laboratory procedures. O. Gon and P. Haworth of the South African Institute for Aquatic Biodiversity generously gave permission to use the illustrations in Fig. 2. We also thank D. Pratt for work on the figures. We received many useful comments from the 3 referees. J.T.E. was supported by US National Science Foundation grant ANT 04-36190.

\section{LITERATURE CITED}

Alexander RM (1968) Animal mechanics. Sidgwick \& Jackson, London

Anderson RO, Gutreuter SJ (1983) Length, weight, and associated structural indices. In: Nielsen LA, Johnson DL (eds) Fisheries techniques. American Fisheries Society, Bethesda, MD, p 283-333

Archer SD, Johnston IA (1989) Kinematics of labriform and subcarangiform swimming in the Antarctic fish Notothenia neglecta. J Exp Biol 143:195-210

Balguerías E (1989) Resultados de la campaña 'Antártida 8611'. Publicaciones Especiales Instituto Español de Oceanografía, Vol 2. Instituto Español de Oceanografía, Madrid 2:

Barrera-Oro E (2002) The role of fish in the Antarctic marine food web: differences between inshore and offshore waters in the southern Scotia Arc and west Antarctic Peninsula. Antarct Sci 14:293-309

Barrera-Oro ER, Casaux RJ (1990) Feeding selectivity in Notothenia neglecta, Nybelin, from Potter Cove, South Shetland Islands, Antarctica. Antarct Sci 2:207-213

Barrera-Oro ER, Casaux RJ (1992) Age estimation for juvenile Notothenia rossii from Potter Cove, South Shetland Islands. Antarct Sci 4:131-136

Barrera-Oro ER, Casaux RJ (1996) Validation of age determination in Notothenia coriiceps by means of a tag/ recapture experiment at Potter Cove, South Shetland Islands. Arch Fish Mar Res 43:205-216

Barrera-Oro ER, Casaux RJ (2008) General ecology of coastal fish from the South Shetland Island and West Antarctic Peninsula areas. In: Wiencke C, Ferreyra G, Abele D, Marenssi S (eds) The Antarctic ecosystem of Potter Cove, King-George Island (Isla 25 de Mayo). Synopsis of research performed 1999-2006 at the Dallmann Laboratory and Jubany Station. Berichte zur Polar- und Meeresforschung 571. AWI, Bremerhaven, p 95-110

Barrera-Oro E, Marschoff E (2007) Information on the status of fjord Notothenia rossii, Gobionotothen gibberifrons and Notothenia coriiceps in the lower South Shetland Islands, derived from the 2000-2006 monitoring program at Potter Cove. CCAMLR Sci 14:83-87

Barrera-Oro ER, Piacentino GLM (2007) Feeding habits of juvenile Trematomus newnesi (Pisces, Nototheniidae) at Potter Cove, South Shetland Islands, Antarctica. Polar Biol 30:789-796

Barrera-Oro E, Winter D (2008) Age composition and feeding ecology of early juvenile Notothenia rossii (Pisces, Nototheniidae) at Potter Cove, South Shetland Islands, Antarctica. Antarct Sci 20:339-341
Barrera-Oro ER, Alescio NS, Moreira E, Marschoff ER (2010) Using scales to clarify the transition from blue phase to brown phase fingerling in Notothenia rossii from the South Shetland Islands. Polar Biol 33:877-884

Blaxter JHS (1988) Pattern and variety in development. In: Hoar WS, Randall DJ (eds) Fish physiology, Vol XIA. Academic Press, San Diego, CA, p 1-58

Brandt A (1999) On the origin and evolution of Antarctic Peracarida (Crustacea, Malacostraca). Sci Mar 63(Suppl 1): 261-274

Brandt A (2000) Hypotheses on Southern Ocean peracarid evolution and radiation (Crustacea, Malacostraca). Antarct Sci 12:269-275

Brandt A, Gooday AJ, Brandão SN, Brix S and others (2007) First insights into the biodiversity and biogeography of the Southern Ocean deep sea. Nature 447:307-310

Burchett MS (1982) The ecology of some coastal fish populations at South Georgia. Prog Underw Sci 7:15-20

Burchett MS (1983) Morphology and morphometry of the Antarctic nototheniid Notothenia rossii marmorata. $\mathrm{Br}$ Antarct Surv Bull 58:71-81

Burchett MS, Sayers PJ, North AW, White MG (1983) Some biological aspects of the nearshore fish population at South Georgia. Br Antarct Surv Bull 59:63-74

Busacker GP, Adelman IR, Goolish EM (1990) Growth. In: Schreck CB, Moyle PB (eds) Methods for fish biology. American Fisheries Society, Bethesda, MD, p 363-387

> Campbell HA, Fraser KPP, Peck LS, Bishop CM, Egginton S (2007) Life in the fast lane: the free-ranging activity, heart rate and metabolism of an Antarctic fish tracked in temperate waters. J Exp Mar Biol Ecol 349:142-151

Campbell HA, Fraser KPP, Bishop CM, Peck LS, Egginton S (2008) Hibernation in an Antarctic fish: on ice for winter. PLoS ONE 3:e1743

Casaux R, Barrera-Oro E (2002) Effect of a shore-based sampling programme on Notothenia coriiceps populations. Antarct Sci 14:221-224

> Casaux RJ, Mazzotta AS, Barrera-Oro ER (1990) Seasonal aspects of the biology and diet of nearshore nototheniid fish at Potter Cove, South Shetland Islands, Antarctica. Polar Biol 11:63-72

Corner EDS, Denton EJ, Forster GR (1969) On the buoyancy of some deep-sea sharks. Proc R Soc Lond B Biol Sci 171: 415-429

Davidson D, Marshall T (2010) Are morphometric indices accurate indicators of stored energy in herring Clupea harengus? J Fish Biol 76:913-929

de Ricqles A, Meunier FJ, Castanet J, Francillon-Vieillot H (1991) Comparative microstructure of bone. In: Hall BK (ed) Bone: a treatise, Vol 3. CRC Press, Boca Raton, FL, p 1-77

Deméré TA, Berta A, Adam PJ (2003) Pinnipedimorph evolutionary biogeography. Bull Am Mus Nat Hist 279:32-76

Denton EJ, Marshall NB (1958) The buoyancy of bathypelagic fishes without a gas-filled swimbladder. J Mar Biol Assoc UK 37:753-767

> DeVries AL, Eastman JT (1978) Lipid sacs as a buoyancy adaptation in an Antarctic fish. Nature 271:352-353

DeWitt HH, Heemstra PC, Gon O (1990) Nototheniidae. In: Gon O, Heemstra PC (eds) Fishes of the Southern Ocean. J.L.B. Smith Institute of Ichthyology, Grahamstown, p 279-331

Donaldson EM, Fagerlund UHM, Higgs DA, McBride JR (1979) Hormonal enhancement of growth. In: Hoar WS, Randall DJ, Brett JR (eds) Fish physiology, Vol VIII. Bioen- 
ergetics and growth. Academic Press, New York, NY, p 455-597

Eastman JT (1993) Antarctic fish biology: evolution in a unique environment. Academic Press, San Diego, CA

Eastman JT (2000) Antarctic notothenioid fishes as subjects for research in evolutionary biology. Antarct Sci 12: 276-287

Eastman JT (2005) The nature of the diversity of Antarctic fishes. Polar Biol 28:93-107

- Eastman JT, Barrera-Oro ER (2010) Buoyancy studies of three morphs of the Antarctic fish Trematomus newnesi (Nototheniidae) from the South Shetland Islands. Polar Biol 33:823-831

Eastman JT, DeVries AL (1981) Buoyancy adaptations in a swim-bladderless Antarctic fish. J Morphol 167:91-102

Eastman JT, DeVries AL (1982) Buoyancy studies of notothenioid fishes in McMurdo Sound, Antarctica. Copeia 1982: 385-393

Eastman JT, Sidell BD (2002) Measurements of buoyancy for some Antarctic notothenioid fishes from the South Shetland Islands. Polar Biol 25:753-760

Fenaughty JM, Eastman JT, Sidell BD (2008) Biological implications of low condition factor 'axe handle' specimens of the Antarctic toothfish, Dissostichus mawsoni, from the Ross Sea. Antarct Sci 20:537-551

Fyler CA, Reeder TW, Berta A, Antonelis G, Aguilar A, Androukaki E (2005) Historical biogeography and phylogeny of monachine seals (Pinnipedia: Phocidae) based on mitochondrial and nuclear DNA data. J Biogeogr 32: 1267-1279

Gon O, Heemstra PC (eds) (1990) Fishes of the Southern Ocean. J.L.B. Smith Institute of Ichthyology, Grahamstown

Jobling M (2002) Environmental factors and rates of development and growth. In: Hart PJB, Reynolds JD (eds) Handbook of fish biology and fisheries, Vol 1. Fish biology. Blackwell, Malden, MA, p 97-122

Johnston IA, Camm JP (1987) Muscle structure and differentiation in pelagic and demersal stages of the Antarctic teleost Notothenia neglecta. Mar Biol 94:183-190

Jones CD, Kock KH, Ashford J, DeVries A and others (2003) Standing stock, biology, diet and spatial distribution of demersal finfinsh from the 2003 US AMLR bottom trawl survey of the South Shetland Islands (Subarea 48.1). WGFSA-03/38, Rev.1. CCAMLR, Hobart

Kellermann A (1991) Egg and larval drift of the Antarctic fish Notothenia coriiceps. Cybium 15:199-210

Kock KH (1985) Krill consumption by Antarctic notothenioid fishes. In: Siegfried WR, Condy PR, Laws RM (eds) Antarctic nutrient cycles and food webs. Springer-Verlag, Berlin, p 437-444

Kock KH (1989) Reproduction in fish around Elephant Island. Arch Fischwiss 39:171-210

Kock KH, Kellermann A (1991) Reproduction in Antarctic notothenioid fish. Antarct Sci 3:125-150

> Kontula T, Kirilchik SV, Väinölä R (2003) Endemic diversification of the monophyletic cottoid fish species flock in Lake Baikal explored with mtDNA sequencing. Mol Phylogenet Evol 27:143-155

LeDuc RG, Robertson KM, Pitman RL (2008) Mitochondrial sequence divergence among Antarctic killer whale eco- types is consistent with multiple species. Biol Lett 4: 426-429

Lindsey CC (1978) Form, function, and locomotory habits in fish. In: Hoar WS, Randall DJ (eds) Fish physiology, Vol VII. Academic Press, New York, NY, p 1-100

McCune AR, Carlson RL (2004) Twenty ways to lose your bladder: common natural mutants in zebrafish and widespread convergence of swim bladder loss among teleost fishes. Evol Dev 6:246-259

Mommsen TP (1998) Growth and metabolism. In: Evans DH (ed) The physiology of fishes, 2nd edn. CRC Press, Boca Raton, FL, p 65-97

- Near TJ, Cheng CHC (2008) Phylogenetics of notothenioid fishes (Teleostei: Acanthomorpha): inferences from mitochondrial and nuclear gene sequences. Mol Phylogenet Evol 47:832-840

Near TJ, Russo SE, Jones CD, DeVries AL (2003) Ontogenetic shift in buoyancy and habitat in the Antarctic toothfish, Dissostichus mawsoni (Perciformes: Nototheniidae). Polar Biol 26:124-128

Near TJ, Pesavento JJ, Cheng CHC (2004) Phylogenetic investigations of Antarctic notothenioid fishes (Perciformes: Notothenioidei) using complete gene sequences of the mitochondrial encoded 16S rRNA. Mol Phylogenet Evol 32:881-891

Near TJ, Jones CD, Eastman JT (2009) Geographic intraspecific variation in buoyancy within Antarctic notothenioid fishes. Antarct Sci 21:123-129

North AW (1996) Locomotory activity and behaviour of the Antarctic teleost Notothenia coriiceps. Mar Biol 126: $125-132$

Olsen S (1954) South Georgian cod (Notothenia rossii marmorata). Norsk Hvalfangst-Tidende 43:233-242

Pelster B (1998) Buoyancy. In: Evans DH (ed) The physiology of fishes, 2nd edn. CRC Press, Boca Raton, FL, p 25-42

- Sanchez S, Dettaï A, Bonillo C, Ozouf-Costaz C, Detrich HW III, Lecointre G (2007) Molecular and morphological phylogenies of the Antarctic teleostean family Nototheniidae, with emphasis on the Trematominae. Polar Biol 30: 155-166

Schluter D (2000) The ecology of adaptive radiation. Oxford University Press, Oxford

Schluter D (2009) Evidence for ecological speciation and its alternative. Science 323:737-741

Sideleva VG (1996) Comparative character of the deepwater and inshore cottoid fishes endemic to Lake Baikal. J Fish Biol 49(Suppl A):192-206

Sokal RR, Rohlf FJ (1981) Biometry, 2nd edn. WH Freeman, San Francisco, CA

Tiedtke JE, Kock KH (1989) Structure and composition of the demersal fish fauna around Elephant Island. Arch Fischwiss 39:143-169

Wainwright SA (1983) To bend a fish. In: Webb PW, Weihs D (eds) Fish biomechanics. Praeger, New York, NY, p 68-91

Wainwright SA, Biggs WD, Currey JD, Gosline JM (1976) Mechanical design in organisms. Princeton University Press, Princeton, NJ

Weatherley AH (1972) Growth and ecology of fish populations. Academic Press, London

Submitted: April 6, 2011; Accepted: July 6, 2011

Proofs received from author(s): September 18, 2011
Editorial responsibility: James McClintock

Birmingham, Alabama, USA 